\title{
Oral Phosphodiesterase Type 5 Inhibitors in Recurrent Priapism Complicating Thalassemia Intermedia: A Case Report
}

\author{
Davood Maleki \\ Hematology \& Oncology Ward, Urmia University of Medical Sciences, Urmia, Iran \\ Email: davood.maleki@gmail.com
}

Received 24 April 2014; revised 18 May 2014; accepted 5 June 2014

Copyright (C) 2014 by author and Scientific Research Publishing Inc. This work is licensed under the Creative Commons Attribution International License (CC BY). http://creativecommons.org/licenses/by/4.0/

(c) (i) Open Access

\begin{abstract}
Recurrent priapism is a rare, serious and difficult to treat complication of some hematological disorders, for which no standard therapy exists. This study reports a case of a 42-year-old man with thalassemia intermedia complicated by recurrent episodes of priapism. To prevent priapism recurrences, a trial of PDE5is use was initiated. One day after initiation of a PDE5i (25 mg sildenafil repeated every 8 hours), priapism was improved. For 3 weeks, the patient reported improvement, without experiencing any episodes of priapism and a normal physiologic erectile function. Four weeks after treatment he experienced priapism reoccurrence and doubling of the Sildenafil was not effective. Gonadotropin-releasing hormone agonist initiated and one week after initiatin of new drug he improved. He was free of priapism episodes for more than 2 years afterward. PDE5 deregulation seems to be an underling pathologic mechanism of recurrent priapism at least in thalassemia intermedia patients. It appears that PDE5is may have a role in the management of such patients and further testing in clinical trials is needed.
\end{abstract}

\section{Keywords}

PDE5is, Reccurent Priapism, Thalassemia Intermedia, PDE5is for Priapism, Gonadotropin-Releasing Hormone Agonist for Priapism

\section{Introduction}

Priapism is an abnormal persistent erection of the penis. It is an undesired prolonged erection unrelated to sexual stimulation and unrelieved by ejaculation [1].

Stuttering or recurrent priapism is characterised by spontaneous and prolonged erections, lasting up to 3 hours, 
which usually ends with spontaneous penile detumescence [2]. Recurrent priapism is encountered in patients with sickle cell disease [3]-[5]. A few case reports of recurrent priapism occurring in thalassemia intermedia especially after splenectomy [6] [7], hemoglobin-E beta thalassemia [8], hereditary spherocytosis [9] and glucose6-phosphate dehydrogenase (G6PD) deficiency [10] [11] have been documented in the literature.

Recurrent priapism is a rare but serious and difficult to treat condition. The pathophysiology of this type of priapism is not fully elucidated [12] [13]. A mechanism based on dysregulation of Nitric oxide and phosphodiesterase type 5 in the corporal smooth muscle has been proposed [2] [14]-[16]. Yet no standard therapy exists for the prevention of recurrent ischemic priapism [17] [18].

\section{Case Report}

A 42-year-old male patient with thalassemia intermedia was admitted with recurrent episodes of priapism. He underwent splenectomy at age 23, for enlarged spleen and increased red blood cell transfusion demand, since then he had received transfusions no more than once every three months. He has received deferoxamine infusions regularly. He is married and has three children. He had been facing frequent episodes of priapism on a daily manner for 6 years which mandated multiple decompressive procedures. During the last two years, he had experienced one or two episodes of priapism each day, and lost his social acts and was bedridden. These episodes occurred after midnight every night and sometimes in the afternoon, and were unrelated to sexual arousal or activity. He was a cigarette smoker and had chronic bronchitis.

On physical examination, he had pallor, icterus, diffuse wheezing. The penis was circumcised with multiple scars of decompressive punctures.

His hemoglobin was $10.5 \mathrm{~g} / \mathrm{dl}$, he matocrit $34 \%$, MCV 65 fl, platelets $274 \times 10^{9} / \mathrm{L}$, and WBC $6.9 \times 10^{9} / \mathrm{L}$. Peripheral smear showed poikilocytosis, hypochromia, microcytosis and nucleated RBCs without any sickle cells. Hemoglobin electrophoresis showed $\mathrm{Hb} \mathrm{A}, \mathrm{A}_{2}$ and $\mathrm{F}$ to be $94 \%, 5.6 \%$ and $0.4 \%$ respectively. His serum ferrittin level was $1750 \mathrm{ng} / \mathrm{ml}$.

His clinical picture, blood count, peripheralsmear and electrophoresis were consistent with thalassemia intermedia.

He was treated with sildenafil, a PDE5is, 25 mg every 8 hours. The day after initiation of sildenafil priapism did not occur and on the third event free day the patient was discharged. For 3 weeks, the patient reported improvement, without experiencing any episodes of priapism and a normal physiologic erectile function. Four weeks after treatment he experiences priapism reoccurrence and doubling of the Sildenafil was not effective. Gonadotropin-releasing hormone agonist initiated and one week after initiatin of new drug he improved. He was free of priapism episodes for more than 2 years afterward, albeit with the loss of libido and erectile function.

\section{Discussion}

Recurrent priapism is a very uncommon, serious and difficult to treat complication of some hematological disorders, for which no standard therapy exists.

Episodes of recurrent priapism are treated by home intracavernous self-injections of the alpha-adrenergic agonists [19] [20]. This treatment needs patient admission for verifying drug effectiveness, dose adjustments and patient training on the self-injection procedure.

A few medications are reported to be effective in prevention of recurrences, including phosphodiesterase type 5 inhibitors (PDE5is) [4] [14], gonadotropin-releasing hormone agonists [21], antiandrogens [22] [23], ketoconazole plus prednisone [18], oral gabapentin [24] and baclofen [25]. Most reports are based on small trials or case reports. Gonadotropin-releasing hormone agonists, antiandrogens, and ketoconazole plus prednisone, as hormonal manipulations, have been successful in preventing episodes of priapism, but may be associated with the loss of libido and erectile function as seen in this case.

Gabapentin and baclofen have been used successfully to prevent episodes of priapism, but have no clear correlation with its pathophysiology.

Nitric oxide serves a fundamental role in the erectile response by mediating relaxation of smooth muscle. PDE5 inhibitors inhibit breakdown of cGMP and potentiate nitric oxide-mediated penile smooth muscle relaxation for erectile function. A regulatory defect in the nitric oxide pathway has been proposed to account for some patients with priapism, particularly those with sickle cell disease [2] [10] [12] [15]. Successful use of PDE5is in preventing episodes of recurrent priapism has been reported, in sickle cell disease-associated, idiopathic and 
thalassemia intermedia-associated priapism.

This case of thalassemia intermedia-associated recurrent priapism, treated with PDE5is, supports the findings of two previous reports on the effectiveness of PDE5is in recurrent priapism. However, PDE5is didn't prevent episodes for long term.

These observations may show that PDE5 deregulations have a pathogenic role in recurrent priapism. Although it is suggested that PDE5is therapy may be a useful preventative strategy for recurrent priapism, additional evaluation is needed. Gonadotropin-releasing hormone agonist was preventative in this case as reported before that.

\section{References}

[1] Abu Sham'a, R.A.H., Kufri, F.H. and Yassin, I.H. (2008) Stuttering Priapism Complicating Warfarin Therapy in a Patient with Protein C Deficiency. International Journal of Laboratory Hematology, 30, 339-343. http://dx.doi.org/10.1111/j.1751-553X.2007.00963.x

[2] Burnett, A.L., Bivalacqua, T.J., Champion, H.C. and Musicki, B. (2006) Feasibility of the Use of Phosphodiesterase Type 5 Inhibitors in a Pharmacologic Prevention Program for Recurrent Priapism. Journal of Sexual Medicine, 3 , 1077-1084. http://dx.doi.org/10.1111/j.1743-6109.2006.00333.x

[3] Virag, R., Bachir, D., Lee, K. and Galacteros, F. (1996) Preventive Treatment of Priapism in Sickle Cell Disease with Oral and Self-Administered Intracavernous Injection of Etilefrine. Urology, 47, 777-781. http://dx.doi.org/10.1016/S0090-4295(96)00027-1

[4] Rogers, Z.R. (2005) Priapism in Sickle Cell Disease. Hematology/Oncology Clinics of North America, 19, 917-928. http://dx.doi.org/10.1016/j.hoc.2005.08.003

[5] Prabhakaran, K., Jacobs, B.L., Smaldone, M.C. and Franks, M.E. (2007) Stuttering Priapism Associated with Hereditary Spherocytosis. The Canadian Journal of Urology, 14, 3702-3704.

[6] Jackson, N., Franklin, I.M. and Hughes, M.A. (1986) Recurrent Priapism Following Splenectomy for Thalassaemiaintermedia. British Journal of Surgery, 73, 678. http://dx.doi.org/10.1002/bjs.1800730832

[7] Macchia, P., Massei, F., Nardi, M., Favre, C., Brunori, E. and Barba, V. (1990) Thalassemia Intermedia and Recurrent Priapism Following Splenectomy. Haematologica, 75, 486-487.

[8] Sharma, R., Prakash, R., Kamboj, S. and Jain, V. (2008) Hemoglobin-E Beta Thalassemia Presenting with Recurrent Priapism-A Rare Complication. American Journal of Hematology, 83, 257. http://dx.doi.org/10.1002/ajh.21110

[9] Prabhakaran, K., Jacobs, B.L., Smaldone, M.C. and Franks, M.E. (2007) Stuttering Priapism Associated with Hereditary Spherocytosis. The Canadian Journal of Urology, 14, 3702-3704.

[10] Burnett, A.L. and Bivalacqua, T.J. (2008) Glucose-6-Phosphate Dehydrogenase Deficiency: An Etiology for Idiopathic Priapism? Journal of Sexual Medicine, 5, 237-240.

[11] Finley, D.S. (2008) Glucose-6-Phosphate Dehydrogenase Deficiency Associated Stuttering Priapism: Report of a Case. Journal of Sexual Medicine, 5, 2963-2966. http://dx.doi.org/10.1111/j.1743-6109.2008.01007.x

[12] Tzortzis, V., Mitrakas, L., Gravas, S., Mamoulakis, C., Meissner, A., Kyriakou, D. and Melekos, M.D. (2009) Oral Phosphodiesterase Type 5 Inhibitors Alleviate Recurrent Priapism Complicating Thalassemia Intermedia: A Case Report. Journal of Sexual Medicine, 6, 2068-2071. http://dx.doi.org/10.1111/j.1743-6109.2009.01285.X

[13] Wen, J., Jiang, X., Dai, Y., Zhang, Y., Tang, Y., Sun, H., Mi, T., Kellems, R.E., Blackburn, M.R. and Xia, Y. (2010) Adenosine Deaminase Enzyme Therapy Prevents and Reverses the Heightened Cavernosal Relaxation in Priapism. Journal of Sexual Medicine, 7, 3011-3022. http://dx.doi.org/10.1111/j.1743-6109.2009.01552.x

[14] Burnett, A.L. (2003) Priapism Pathophysiology: Clues to Prevention. International Journal of Impotence Research, 15, S80-S85. http://dx.doi.org/10.1038/sj.ijir.3901077

[15] Champion, H.C., Bivalacqua, T.J., Takimoto, E., Kass, D.A. and Burnett, A.L. (2005) Phosphodiesterase-5A Dysregulation in Penile Erectile Tissue Is a Mechanism of Priapism. Proceedings of the National Academy of Sciences of the USA, 102, 1661-1666. http://dx.doi.org/10.1073/pnas.0407183102

[16] Burnett, A.L. (2008) Molecular Pharmacotherapeutic Targeting of PDE5 for Preservation of Penile Health. Journal of Andrology, 29, 3-14. http://dx.doi.org/10.2164/jandrol.107.003483

[17] Muneer, A, Minhas, S., Arya, M. and Ralph, D.J. (2008) Stuttering Priapism-A Review of the Therapeutic Options. International Journal of Clinical Practice, 62, 1265-1270. http://dx.doi.org/10.1111/j.1742-1241.2008.01780.x

[18] Abern, M.R. and Levine, L.A. (2009) Ketoconazole and Prednisone to Prevent Recurrent Ischemic Priapism. Journal of Urology, 182, 1401-1406. http://dx.doi.org/10.1016/j.juro.2009.06.040

[19] McDonald, M. and Santucci, R.A. (2004) Successful Management of Stuttering Priapism Using Home Self-Injections 
of the Alpha-Agonist Metaraminol. International Braz J Urol, 30, 121-122. http://dx.doi.org/10.1590/S1677-55382004000200007

[20] Ralph, D.J., Pescatori, E.S., Brindley, G.S. and Pryor, J.P. (2001) Intracavernosal Phenylephrine for Recurrent Priapism: Self-Administration by Drug Delivery Implant. Journal of Urology, 165, 1632. http://dx.doi.org/10.1016/S0022-5347(05)66371-9

[21] Levine, L.A. and Guss, S.P. (1993) Gonadotropin-Releasing Hormone Analogues in the Treatment of Sickle Cell Anemia-Associated Priapism. Journal of Urology, 150, 475-477.

[22] Dahm, P., Rao, D.S. and Donatucci, C.F. (2002) Antiandrogens in the Treatment of Priapism. Urology, 59, 138. http://dx.doi.org/10.1016/S0090-4295(01)01492-3

[23] Rachid-Filho, D., Cavalcanti, A.G., Favorito, L.A., Costa, W.S. and Sampaio, F.J. (2009) Treatment of Recurrent Priapism in Sickle Cell Anemia with Finasteride: A New Approach. Urology, 74, 1054-1057. http://dx.doi.org/10.1016/j.urology.2009.04.071

[24] Khot, R. and Aher, A. (2012) Sickle Cell Disease with Recurrent Priapism. The Journal of the Association of Physicians of India, 60, 62-63.

[25] Rourke, K.F., Fischler, A.H. and Jordan, G.H. (2002) Treatment of Recurrent Idiopathic Priapism with Oral Baclofen. Journal of Urology, 168, 2552-2553. http://dx.doi.org/10.1016/S0022-5347(05)64201-2 